\title{
MERANCANG SISTEM PENGUKURAN REDAMAN TRANSMISI KABEL OPTIK SINGLE MODE JENIS PIGTAIL
}

\author{
Aprinal Adila Asril ${ }^{1 *}$, Yustini ${ }^{2}$, Popy Maria ${ }^{3}$, Putri Azizah Herwita ${ }^{4}$ \\ 1,2,3,4 Jurusan Teknik Elektro, Politeknik Negeri \\ aprina169@gmail.com
}

\begin{abstract}
Optical fiber is a transmission channel made of glass or plastic that is used to transmit light signals from one place to another. Optical fibers, in general, have a basic structure consisting of a fiber core, a fiber coating (cladding), and a protective layer (coating) consisting of an inner jacket. This research discusses the design of the attenuation of the fiber optic transmission measurement system by connection factor. Optical fiber cable used in this research is pigtail type cable with single-mode cable type. The cable used is 10 meters long, which will be installed in the Optical Termination Box. In the Optical Termination Box there are 6 pigtail cables, which are without connections, with a $6 \mathrm{~cm}$ sleeve protection one connection and two connections, also with a $4 \mathrm{~cm}$ sleeve protection one connection and two connections, then use a barrel adapter. In this design testing tools use Light source, Optical Power Meter, and Optical Time Domain Reflectometer). The attenuation value after testing on the protection sleeve $6 \mathrm{~cm} ; 12,330 \mathrm{~dB}$, then the attenuation on the protection sleeve is $4 \mathrm{~cm}$; $12,729 \mathrm{~dB}$. Then attenuation on the barrel adapter; $12,954 \mathrm{~dB}$
\end{abstract}

\section{Keywords : Fiber Optic, Optical Termination Box, Optical Power Meter, Optical Time Domain Reflectometer}

\begin{abstract}
Abstrak - Fiber optik merupakan sebuah saluran transmisi yang terbuat dari kaca atau plastik yang digunakan untuk mentransmisikan sinyal cahaya dari suatu tempat ke tempat lain. Fiber optik pada umumnya memiliki struktur dasar yang terdiri dari inti serat (core), pelapis serat (cladding), dan lapisan pelindung (coating) yang terdiri atas inner jacket. Pada perancangan ini membahas sistem pengukuran redaman transmisi serat optik dengan faktor penyambungan. kabel fiber optik yang digunakan dalam Perancanganini adalah kabel jenis pigtail dengan tipe kabel singlemode. Kabel yang digunakan dengan panjang 10 meter, yang akan di pasang pada Optikal Termination Box. Pada Optikal Termination Box terdapat 6 kabel pigtail, yaitu tanpa sambungan, dengan sleeve protection $6 \mathrm{~cm}$ satu sambungan dan dua sambungan, juga dengan sleeve protection $4 \mathrm{~cm}$ satu sambungan dan dua sambungan, kemudian menggunakan adapter barrel. Alat pengujian Perancanganini menggunakan Light source, Optikal Powe Meter, dan Optikal Time Domain Reflectometer. Setelah dilakukan pengujian nilai redaman pada sleeve protection $6 \mathrm{~cm} ; 12,330 \mathrm{~dB}$, lalu redaman pada sleeve protection $4 \mathrm{~cm} ; 12,729 \mathrm{~dB}$. Kemudian redaman pada adapter barrel ; 12,954 dB.
\end{abstract}

Kata Kunci : Fiber Optik, Optikal Termination Box, Optikal Power Meter, Optikal Time Domain Reflectometer

\section{PENDAHULUAN}

Meningkatnya kebutuhan akan komunikasi data, terutama sistem komunikasi serat optik yang pada akhir-akhir ini berkembang pesat mendorong untuk membuat dan mengembangkan berbagai metode dan teknologi yang dapat digunakan untuk mengakomodasi kebutuhan dalam kapasitas besar dan kecepatan tinggi dari sistem tersebut. Seiring dengan peningkatan dan pengembangan menggunakan kabel serat optik sebagai media transmisi data, maka juga sering terjadi faktor hilangnya informasi yang diakibatkan oleh rugi-rugi yang terjadi disepanjang kabel serat optik, salah satu rugi-rugi tersebut adalah rugi daya yang diakibatkan oleh redaman di sepanjang kabel serat optik, yang mengakibatkan perubahan daya dari pemancar optik (Transmitter) hingga mencapai di penerima optik (Receiver)[1]

Permasalahan utama dan yang sering terjadi dalam serat optik adalah hilang nya energi cahaya di dalam serat optik. Pada dasarnya hilangnya cahaya di dalam serat optik disebabkan beberapa hal yaitu bahan inti serat optik yang kotor dan cahaya dibelokan kearah yang salah, penyambungan yang kurang akurat dan sebagainya.[2]

Berdasarkan dari permasalaah diatas maka penulis akan merancang suatu sistem pengukuran redaman pada kabel optik single mode jenis pigtail dengan menggunakan beberapa metoda penyambungan dan akan dilakukan pengkajian dalam menganalisis redaman pada media transmisi serat optik yang diakibatkan oleh metode penyambungan yang dilakukan, penyambungan konektor instalasi serat optik pada media transmisi

Adapun tujuan dan urgensi Perancangan in adalah merancang sistem pengukuran redaman transmisi kabel optik single mode jenis pigtail yang dapat diaplikasikan untuk modul praktikum serat optik dan uji kompentensi skema optik menggunakan OPM 
dan OTDR untuk skema Perancangan terapan unggulan perguruan tinggi

\section{METODE}

\subsection{Alur Perancangan}

Pada proses perancangan Perancangan ini menggunakan metode eksperimen yang terdiri dari diagram alur Perancangan yang dapat ditunjukan pada Gambar.5 sehingga terbentuklah sebuah sistem yang menjadi sebuah tujuan, kemudian data hasil kerja yang didapatkan di analisa sehingga bisa ditarik sebuah kesimpulan

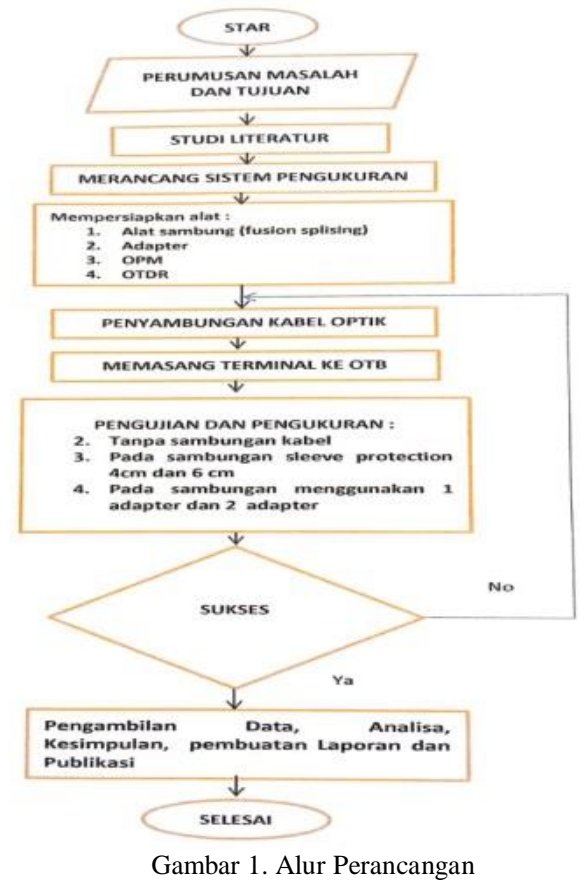

\subsection{Studi Literatur}

Dalam tahap ini dilakukan kegiatan pembahasan literatur dari suatu Perancangan yaitu merancang Sistem Pengukuran Redaman Transmisi Kabel Optik Single Mode Jenis Pigtail, , dimana penulis mengumpulkan data-data serta mempelajari teori dasar yang relevan dari berbagai sumber seperti buku, internet, narasumber dan Perancangan yang telah dilakukan yang berkaitan dengan Perancangan yang akan dilakukan penulis.

\subsection{Desain Rancangan}

Dalam tahap ini kegiatan yang dilakukan penulis adalah membuat sebuah desain rancangan dalam untuk pengukuran redaman transmisi kabel optik seperti gambar 2 .

\subsection{Pengujian dan Pengukuran}

Pada tahap ini penulis melakukan tahap pengujian dan pengukuran redaman setiap kabel hasil sambungan yang dilakukan sesuai dengan rancangan.
2.5. Analisa, Penarikan Kesimpulan, dan Pembuatan Laporan

Merupakan tahap akhir dalam proses pembuatan Perancangan yaitu setelah semua data pengujian terkumpul kemudian penulis akan melakukan analisa data tersebut, selanjutnya menarik kesimpulan sebagai bahan penyusun laporan.

\subsection{Bahan Perancangan}

Pada Perancangan ini dibutuhkan beberapa komponen-komponen untuk dapat menunjang sitem kerja alat yaitu Kabel optik Single Mode jenis pigtail 10 meter, Alkohol 95\%, Kain Majun, Protection Sleeve, Tissues, adapter dan OTB

\subsection{Alat-Alat Perancangan}

Fusion splicer, OPM, OTDR, Obeng, Tang potong, tube cutter

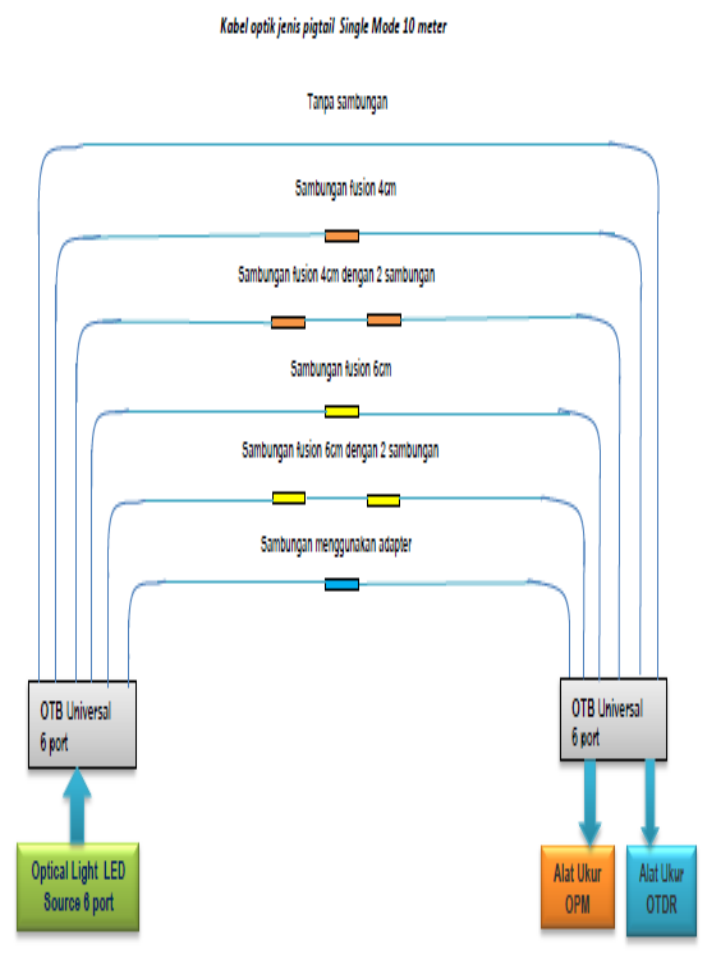

Gambar 2 Rancangan pengukuran redaman transmisi kabel optik

\subsection{Tinjuan Pustaka}

Dalam sistem perkembangan informasi dan komunikasi yang demikian cepat, jaringan serat optik sebagai media transmisi yang banyak digunakan dan dipercaya dapat memenuhi kebutuhan layanan saat ini dan dimasa mendatang. Serat optik merupakan media transmisi yang menggunakan media cahaya sebagai penyalur informasi (data) dimana menawarkan kecepatan data yang lebih besar sepanjang jarak yang lebih jauh dan berbagai keunggulan lain. Sistem komunikasi serat optik dengan cepat mampu bersaing menggantikan sistem-sistem komunikasi lain dengan kelebihan serat optik yaitu memiliki bandwidth yang besar, redaman transmisi kecil, kemudahan 
penambahan kapasitas, serta tingkat ketersediaan yang tinggi dan jaringan transport yang handal.[2]

\section{A. Media Serat Optik}

Pada dasarnya kabel serat optik merupakan media transmisi, yang dimana pada media serat optik adalah salah satu solusi dari berbagai permasalahan dalam dunia telekomunikasi, seperti peningkatan jumlah kanal yang tersedia, tersedianya bandwidth yang besar, mampu mengirim data dengan kapasitas besar dan berbagai kendala dalam komunikasi lainya [3]

\section{Struktur Kabel Serat Optik}

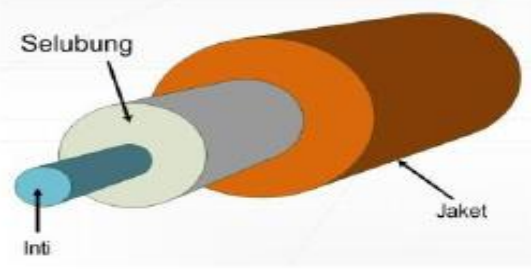

Gambar 3. Struktur Serat Optik

Serat optik memiliki tiga bagian utama yaitu core, cladding dan coating. Struktur serat optik dapat dilihat pada gambar 3 .

a. Core (inti), berfungsi sebagai media pemandu cahaya (guided medium) atau tempat perambatan cahaya dari satu titik ke titik yang lainnya. Core terbuat dari bahan kaca dengan kualitas sangat tinggi dan memiliki diameter 5-10 $\mu \mathrm{m}$ dimana ukuran core akan mempengaruhi karakteristik serat optik.

b. Cladding (selubung), berfungsi sebagai bidang batas pemantulan agar cahaya optik yang dirambatkan dapat dipantulkan total lagi kedalam core sehingga cahaya dapat dipandu sampai diujung lainnya. Cladding terbuat dari bahan gelas dengan indeks bias lebih kecil dari core dan cladding akan mempengaruhi perambatan cahaya pada core (mempengaruhi besarnya sudut kritis).

c. Coating (jaket), berfungsi sebagai pelindung mekanis serat optik sehingga serat optik lebih tahan terhadap gangguan eksternal. Coating terbuat dari bahan plastik dan juga untuk tempat kode warna dari tiap- tiap tube.[3]

\section{Jenis-Jenis Serat Optik}

Jaringan fiber optik terdiri dari beberapa jenis serat, yang biasanya dapat dengan mudah diketahui dengan melihat transmitter (media transmisi data) yang digunakannya. Berikut ini jenis-jenis serat optik :

\section{a. Single Mode}

Kabel jaringan fiber optik jenis single mode memiliki inti (core) yang relatif kecil, dengan diameter sekitar 0.00035 inch atau 9 micron. Jenis kabel fiber optik yang satu ini menggunakan tranmitter light source semikonduktor yang mengirimkan sinar light source inframerah dengan panjang gelombang mencapai 1300-1550 nm. Disebut 'single mode' karena penggunaan kabel fiber optik ini hanya memungkinkan terjadinya satu modus cahaya saja yang dapat tersebar melalui inti pada suatu waktu. [2]

\section{b.Multi Mode}

Muliti mode merupakan jenis kabel fiber optik yang memiliki inti (core) yang lebih besar dibanding milik kabel fiber optik jenis single mode yakni berdiameter sekitar 0.0025 inch atau 62.5 micron. Dengan ukuran yang lebih besar, maka penggunaan kabel fiber optik jenis ini memungkinkan ratusan modus cahaya tersebar melalui serat secara bersamaan. Kabel fiber optik multi mode ini menggunakan lightsource sebagai media transmisinya, serta lebih ditujukan untuk kepentingan komersil. [2].
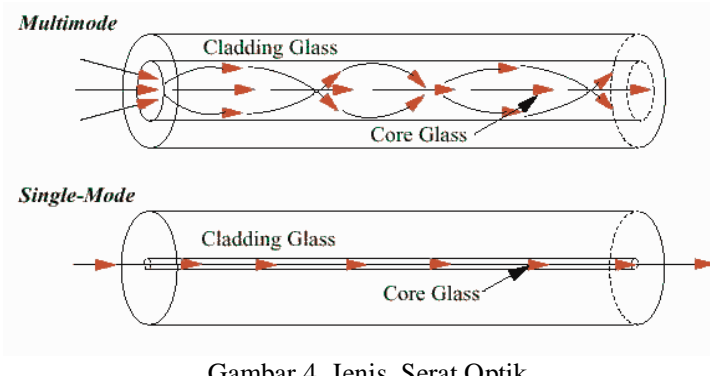

\section{Kabel Patch Cord}

Patch cord adalah kabel fiber optik dengan panjang tertentu yang sudah terpasang konektor di ujungnya. digunakan untuk menghubungkan antar perangkat atau ke koneksi telekomunikasi. Patch cord adalah kabel fiber indoor yang dipakai hanya untuk di dalam ruangan saja. Ada yang simplex (1 core) dan ada pula yang duplex (2 core), Single mode dan Multimode. Patch cord mempunyai banyak sekali jenis konektor, karena masing-masing perangkat / alat yang digunakan mempunyai tipe yang berbeda pula disesuaikan dengan kebutuhan. [4]

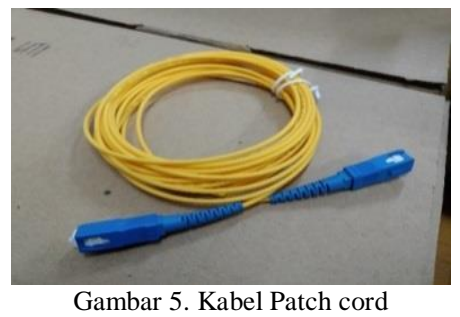

\section{B. Konektor Serat Optik}

Konektor optik merupakan salah satu perlengkapan kabel serat optik yang berfungsi sebagai penghubung serat. Konektor ini mirip dengan konektor listrik dalam hal fungsi dan tampilan luar tetapi konektor pada serat optik memiliki ketelitian yang lebih tinggi. Konektor diperlukan apa bila sewaktu-waktu serat akan dilepas saat diperlukan suatu penggantian transmitter atau receiver maupun untuk melakukan 
suatu kegiatan perawatan maupun pengukuran. Syaratsyarat konektor yang baik adalah:

1. Kehilangan daya cukup rendah.

2. Kemampuan pengulangan.

3. Dapat diprediksi, artinya konektor memiliki efisiensi yang sama jika beberapa konektor sejenis dikombinasi.

4. Umurnya panjang. Tidak ada penurunan efisiensi dalam waktu yang lama.

5. Bahan konektor kuat terhadap tekanan.

6. Kompatibel dengan lingkungan, penyambungan dapat dilakukan pada berbagai variasi temperatur, tekanan tinggi, tahan terhadap getaran, dalam kondisi kelembaban dan kotoran mudah menggunakannya.

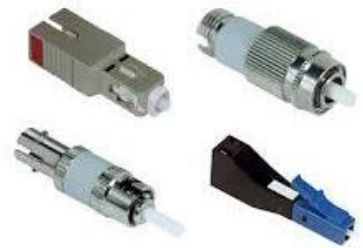

Gambar 6. Jenis Konektor Serat Optik

\section{Redaman Transmisi Serat Optik [3]}

Redaman adalah turunanya level tegang sinyal yang diterima akibat karakteristik media. Sehingga redaman merupakan gangguan dalam sistem komunikasi yang mempengaruhi kinerja dari sistem komunikas. Pada sistem komunikasi serat optik redaman tergantung dari beberapa keadaan. Tetapi yang utama adalah redaman tergantung pada panjang gelombang yang digunakan. Redaman $(\alpha)$ sinyal atau rugi-rugi serat optik didefenisikan sebagai perbandingan antara daya output optik (Pout) terhadap daya input optik (Pin) sepanjang serat L, dimana dapat ditunjukkan pada Persamaan 1. Menurut rekomendasi ITU-T, kabel serat optik harus mempunyai koefisien redaman $0.5 \mathrm{~dB} / \mathrm{km}$ untuk panjang gelombang $1310 \mathrm{~nm}$ dan $0.4 \mathrm{~dB} / \mathrm{km}$ untuk panjang gelombang $1550 \mathrm{~nm}$. Tapi besarnya koefisien ini bukan merupakan nilai yang mutlak, karena harus mempertimbangkan proses pabrikasi, desain komposisi serat, dan desain kabel. Untuk itu terdapat range redaman yang masih diijinkan yaitu $0.4 \mathrm{~dB} / \mathrm{km}$ untuk panjang gelombang $1310 \mathrm{~nm}$ dan $0.3 \mathrm{~dB} / \mathrm{km}$ untuk panjang gelombang $1550 \mathrm{~nm}$.

$$
\begin{array}{ll}
\alpha(d B) & =\frac{10}{L} \log \left(\frac{\text { Pin }}{\text { Pout }}\right) \\
\text { dengan } \quad & \mathrm{L}=\text { Panjang serat optik }(\mathrm{km}) \\
& \text { Pin = Daya input optik }(\mathrm{dBm}) \\
& \text { Pout = Daya output optik }(\mathrm{dBm}) \\
\mathrm{dB} / \mathrm{km} \text { = Redaman perkilometer. }
\end{array}
$$

Redaman penyambungan serat optik seperti pada persamaan berikut ini :

$$
\alpha \mathrm{ST}=\alpha \mathrm{S} . \mathrm{Y}
$$

\footnotetext{
dengan $\quad \alpha \mathrm{ST}=$ Redaman penyambungan $(\mathrm{dB})$ $\alpha \mathrm{S}=$ Redaman per penyambungan $(\mathrm{dB})$ $\mathrm{Y}=$ Jumlah penyambungan
}

Redaman pada konektor serat optik seperti pada persaman berikut ini : $\alpha \mathrm{CT}=\alpha \mathrm{C} . \mathrm{X}$

dengan : $\quad \alpha \mathrm{CT}=$ Redaman konektor $(\mathrm{dB})$

$\alpha \mathrm{C}=$ Redaman per konektor $(\mathrm{dB})$

$\mathrm{X}=$ Jumlah konektor

Redaman serat optik dapat dilihat pada persamaan berikut ini :

$$
\alpha \mathrm{F}=\alpha \mathrm{TOT}-\alpha \mathrm{ST}-\alpha \mathrm{CT}
$$

dengan : $\quad \alpha \mathrm{F}=$ Redaman serat optik $(\mathrm{dB})$ $\alpha \mathrm{TOT}=$ Redaman total serat optik $(\mathrm{dB})$ $\alpha \mathrm{ST}=$ Redaman sambungan $(\mathrm{dB})$ $\alpha \mathrm{CT}=$ Redaman konektor $(\mathrm{dB})$

Redaman total serat optik dapat pada persamaan berikut ini:

$$
\alpha \mathrm{TOT}=\alpha \mathrm{F}+\alpha \mathrm{ST}+\alpha \mathrm{CT}
$$

$$
\begin{array}{cl}
\text { dengan : } & \frac{(\text { Pin-Pout })}{\mathrm{L}}=\text { Redaman total serat optik }(\mathrm{dB}) \\
& \alpha \mathrm{ST}=\text { Redaman serat optik }(\mathrm{dB}) \\
& \alpha \mathrm{S}=\text { Redaman penyambungan }(\mathrm{dB}) \\
& \alpha \mathrm{ST}=\text { Redaman konektor }(\mathrm{dB})
\end{array}
$$

\section{III.HASIL DAN PEMBAHASAN}

\subsection{Hasil}

\subsubsection{Pengukuran Daya dengan OPM}

Pada proses pengukuran ini yang diamati yaitu daya yang dihasilkan setelah cahaya dikeluarkan dari light source. Hasil pengukuran daya sambungan fiber optik menggunakan alat Optikal Power Meter dan Optikal Time-Domain Reflectormeter.

\section{Fiber Optik Pigtail Tanpa Sambungan}

Tabel.1. Hasil Pengukuran Tanpa Sambungan dengan OPM

\begin{tabular}{cccccc}
\hline \multirow{2}{*}{$\lambda$} & \multirow{2}{*}{ Pin } & Pout & \multicolumn{2}{c}{ Pout } & Redaman / \\
\cline { 4 - 5 }$($ watt $)$ & $(\mathrm{dBm})$ & $\mu \mathrm{w}$ & watt & $\alpha(\mathrm{dB})$ \\
\hline 850 & 0,001 & $-6,36$ & 230,2 & 0,0002302 & 0,637894681 \\
\hline 1300 & 0,001 & $-12,11$ & 61,47 & 0,00006147 & $121,133,679$ \\
\hline 1310 & 0,001 & $-12,15$ & 61,16 & 0,00006116 & $121,353,252$ \\
\hline 1490 & 0,001 & $-12,59$ & 55,25 & 0,00005525 & $125,766,772$ \\
\hline 1550 & 0,001 & $-12,51$ & 55,75 & 0,00005575 & $125,375,513$ \\
\hline 1625 & 0,001 & $-12,74$ & 53,22 & 0,00005322 & $127,392,513$ \\
\hline
\end{tabular}

2. Fiber Optik Pigtail menggunakan Sleeve Protection $6 \mathrm{~cm}$ satu sambungan

Tabel 2. Hasil Pengukuran sambungan dengan Sleeve Protection $6 \mathrm{~cm}$ satu sambungan dengan OPM

\begin{tabular}{cccccc}
\hline \multirow{2}{*}{$\lambda$} & \multirow{2}{*}{$\begin{array}{c}\text { Pin } \\
\text { (watt) }\end{array}$} & $\begin{array}{c}\text { Pout } \\
(\mathrm{dBm})\end{array}$ & \multicolumn{2}{c}{ Pout } & Redaman $/$ \\
\cline { 4 - 5 } & & & $\mu(\mathrm{wB})$ \\
\hline 850 & 0,001 & $-6,71$ & 212,6 & 0,0002126 & 0,67243674 \\
\hline 1300 & 0,001 & $-12,35$ & 58,15 & 0,00005815 & $123,545,028$ \\
\hline 1310 & 0,001 & $-12,37$ & 58,47 & 0,00005847 & $123,306,691$ \\
\hline
\end{tabular}




\begin{tabular}{llllll}
1490 & 0,001 & $-12,76$ & 52,91 & 0,00005291 & $127,646,224$ \\
\hline 1550 & 0,001 & $-12,69$ & 53,95 & 0,00005395 & $126,800,855$ \\
\hline 1625 & 0,001 & $-12,89$ & 51,43 & 0,00005143 & $128,878,348$ \\
\hline
\end{tabular}

3. Fiber Optik Pigtail menggunakan Sleeve Protection $6 \mathrm{~cm}$ dua sambungan

Tabel 3. Hasil Pengukuran sambungan dengan Sleeve Protection $6 \mathrm{~cm}$ dua sambungan dengan OPM

\begin{tabular}{cccccc}
\hline \multirow{2}{*}{$\lambda$} & \multirow{2}{*}{$\begin{array}{c}\text { Pin } \\
\text { (watt) }\end{array}$} & \multirow{2}{*}{$\begin{array}{c}\text { Pout } \\
(\mathrm{dBm})\end{array}$} & \multicolumn{2}{c}{ Pout } & Redaman $/$ \\
\cline { 4 - 5 } & & watt & $\alpha(\mathrm{dB})$ \\
\hline 850 & 0,001 & $-6,87$ & 204,6 & 0,0002046 & 0,689094371 \\
\hline 1300 & 0,001 & $-12,56$ & 55,54 & 0,00005554 & $125,539,412$ \\
\hline 1310 & 0,001 & $-12,55$ & 55,56 & 0,00005556 & $125,523,776$ \\
\hline 1490 & 0,001 & $-12,98$ & 50,37 & 0,00005037 & $129,782,805$ \\
\hline 1550 & 0,001 & $-12,9$ & 51,11 & 0,00005111 & $129,149,412$ \\
\hline 1625 & 0,001 & $-13,1$ & 49,02 & 0,00004902 & $130,962,669$ \\
\hline
\end{tabular}

4. Fiber Optik Pigtail menggunakan Sleeve Protection $4 \mathrm{~cm}$ satu sambungan

Tabel 4. Hasil Pengukuran sambungan dengan Sleeve Protection $4 \mathrm{~cm}$ satu sambungan dengan OPM

\begin{tabular}{cccccc}
\hline \multirow{2}{*}{$\lambda$} & \multirow{2}{*}{$\begin{array}{c}\text { Pin } \\
\text { (watt) }\end{array}$} & \multirow{2}{*}{$\begin{array}{c}\text { Pout } \\
(\mathrm{dBm})\end{array}$} & \multicolumn{2}{c}{ Pout } & \multirow{2}{*}{\begin{tabular}{c} 
Redaman $/$ \\
\cline { 4 - 5 }
\end{tabular}} \\
\cline { 4 - 5 } & & & watt & \\
\hline 850 & 0,001 & $-7,05$ & 197,1 & 0,0001971 & 0,705313376 \\
\hline 1300 & 0,001 & $-12,65$ & 53,44 & 0,00005344 & $127,213,355$ \\
\hline 1310 & 0,001 & $-12,72$ & 53,35 & 0,00005335 & $127,286,558$ \\
\hline 1490 & 0,001 & $-13,17$ & 48,34 & 0,00004834 & $131,569,335$ \\
\hline 1550 & 0,001 & $-13,08$ & 49,24 & 0,00004924 & $130,768,196$ \\
\hline 1625 & 0,001 & $-13,27$ & 47,14 & 0,00004714 & $132,661,042$ \\
\hline
\end{tabular}

5. Fiber Optik Pigtail menggunakan Sleeve Protection $4 \mathrm{~cm}$ dua sambungan

Tabel 5. Hasil Pengukuran sambungan dengan Sleeve Protection $4 \mathrm{~cm}$ dua sambungan dengan OPM

\begin{tabular}{cccccc}
\hline \multirow{2}{*}{$\lambda$} & \multirow{2}{*}{$\begin{array}{c}\text { Pin } \\
\text { (watt }\end{array}$} & $\begin{array}{c}\text { Pout } \\
(\mathrm{dBm}\end{array}$ & \multicolumn{2}{c}{ Pout } & Redaman $/$ \\
\cline { 4 - 5 } & ) & ) & $\mu \mathrm{w}$ & watt & $\alpha(\mathrm{dB})$ \\
\hline 850 & 0,001 & $-13,87$ & $\begin{array}{c}40,2 \\
5\end{array}$ & $\begin{array}{c}0,0000402 \\
5\end{array}$ & $\begin{array}{c}139,523,41 \\
2\end{array}$ \\
\hline $\begin{array}{c}130 \\
0\end{array}$ & 0,001 & $-19,64$ & $\begin{array}{c}10,9 \\
7\end{array}$ & $\begin{array}{c}0,0000109 \\
7\end{array}$ & $\begin{array}{c}195,979,33 \\
7\end{array}$ \\
\hline $\begin{array}{c}131 \\
0\end{array}$ & 0,001 & $-19,55$ & $\begin{array}{c}11,2 \\
1\end{array}$ & $\begin{array}{c}0,0000112 \\
1\end{array}$ & $\begin{array}{c}195,039,43 \\
9\end{array}$ \\
\hline $\begin{array}{c}149 \\
0\end{array}$ & 0,001 & $-19,91$ & $\begin{array}{c}10,2 \\
7\end{array}$ & $\begin{array}{c}0,0000102 \\
7\end{array}$ & $\begin{array}{c}198,842,95 \\
6\end{array}$ \\
\hline $\begin{array}{c}155 \\
0\end{array}$ & 0,001 & $-19,78$ & 10,5 & 0,0000105 & $19,788,107$ \\
\hline $\begin{array}{c}162 \\
5\end{array}$ & 0,001 & $-19,97$ & $\begin{array}{c}10,0 \\
7\end{array}$ & $\begin{array}{c}0,0000100 \\
7\end{array}$ & $\begin{array}{c}199,697,05 \\
3\end{array}$ \\
\hline
\end{tabular}

6. Fiber Optik Pigtail menggunakan Adapter Barrel Tabel 6. Hasil Pengukuran menggunakan Adapter Barrel dengan

\begin{tabular}{|c|c|c|c|c|c|}
\hline \multirow{2}{*}{$\lambda$} & \multirow{2}{*}{$\begin{array}{c}\text { Pin } \\
\text { (watt } \\
\text { ) }\end{array}$} & \multirow{2}{*}{$\begin{array}{c}\text { Pout } \\
(\mathrm{dBm} \\
)\end{array}$} & \multicolumn{2}{|c|}{ Pout } & \multirow{2}{*}{$\begin{array}{c}\text { Redaman / } \\
\alpha(\mathrm{dB})\end{array}$} \\
\hline & & & $\mu \mathrm{w}$ & watt & \\
\hline
\end{tabular}

\begin{tabular}{cccccc}
850 & 0,001 & $-6,98$ & $\begin{array}{c}201, \\
2\end{array}$ & 0,0002012 & $\begin{array}{c}0,69637202 \\
4\end{array}$ \\
\hline $\begin{array}{c}130 \\
0\end{array}$ & 0,001 & - & 50,7 & 0,0000507 & $129,439,284$ \\
\hline $\begin{array}{c}131 \\
0\end{array}$ & 0,001 & $\begin{array}{c}- \\
7\end{array}$ & $\begin{array}{c}50,6 \\
5\end{array}$ & $\begin{array}{c}0,0000506 \\
5\end{array}$ & $129,542,055$ \\
\hline $\begin{array}{c}149 \\
0\end{array}$ & 0,001 & $\begin{array}{c}- \\
13,38\end{array}$ & $\begin{array}{c}45,9 \\
0\end{array}$ & $\begin{array}{c}0,0000459 \\
133,818,731\end{array}$ \\
\hline $\begin{array}{c}155 \\
0\end{array}$ & 0,001 & - & $\begin{array}{c}46,5 \\
4\end{array}$ & $\begin{array}{c}0,0000465 \\
4\end{array}$ & $133,217,362$ \\
\hline $\begin{array}{c}162 \\
5\end{array}$ & 0,001 & $\begin{array}{c}- \\
13,53\end{array}$ & $\begin{array}{c}44,4 \\
2\end{array}$ & $\begin{array}{c}0,0000444 \\
2\end{array}$ & $135,242,145$ \\
\hline
\end{tabular}

\subsubsection{Perhitungan Redaman}

1. Redaman tanpa sambungan

Diketahui : Pin $=1 \mathrm{~mW} ;$ Pout $=61,16 \mu \mathrm{W} ; \mathrm{L}=10 \mathrm{~m}$

Ditanya : $\alpha$ ?

Jawab

$\alpha(\mathrm{dB})=10 / \mathrm{L} \log \omega($ Pin/Pout $)$

$\alpha=10 / 10 \log f \circ:(1 \mathrm{~mW} /(61,16 \mu \mathrm{W}))$

$\alpha=10 / 10 \log 0(\llbracket 1 \times 10 \rrbracket \wedge(-3) / \llbracket 61,16 \times 10 \rrbracket \wedge(-6))$

$\alpha=1,21353252 \mathrm{~dB}$

2. Redaman satu sambungan dengan sleeve protection $6 \mathrm{~cm}$

Diketahui : Pin $=1 \mathrm{~mW} ;$ Pout $=58,47 \mu \mathrm{W} ; \mathrm{L}=10 \mathrm{~m}$

Ditanya : $\alpha$ ?

Jawab

$\alpha(\mathrm{dB})=10 / \mathrm{L} \log :($ Pin/Pout $)$

$\alpha=10 / 10 \log 0(1 \mathrm{~mW} /(58,47 \mu \mathrm{W}))$

$\alpha=10 / 10 \log 0:(\llbracket 1 \times 10 \rrbracket \wedge(-3) / \llbracket 58,47 \times 10 \rrbracket \wedge(-6))$

$\alpha=1,23306691 \mathrm{~dB}$

3. Redaman dua sambungan dengan sleeve protection $6 \mathrm{~cm}$

Diketahui : Pin $=1 \mathrm{~mW} ;$ Pout $=55,56 \mu \mathrm{W} ; \mathrm{L}=10 \mathrm{~m}$

Ditanya : $\alpha$ ?

Jawab

$\alpha(\mathrm{dB})=10 / \mathrm{L} \log$ :(Pin/Pout)

$\alpha=10 / 10 \log :(1 \mathrm{~mW} /(55,56 \mu \mathrm{W}))$

$\alpha=10 / 10 \log :(\llbracket 1 \times 10 \rrbracket \wedge(-3) / \llbracket 55,56 \times 10 \rrbracket \wedge(-6))$

$\alpha=1,25523776 \mathrm{~dB}$

4. Redaman satu sambungan dengan sleeve protection $4 \mathrm{~cm}$

Diketahui : Pin $=1 \mathrm{~mW} ;$ Pout $=53,35 \mu \mathrm{W} ; \mathrm{L}=10 \mathrm{~m}$

Ditanya : $\alpha$ ?

Jawab

$\alpha(\mathrm{dB})=10 / \mathrm{L} \log :(\operatorname{Pin} /$ Pout $)$

$\alpha=10 / 10 \log \ldots(1 \mathrm{~mW} /(53,35 \mu \mathrm{W}))$

$\alpha=10 / 10 \log$ ( $(1 \times 10 \rrbracket \wedge(-3) / \llbracket 3,35 \times 10 \rrbracket \wedge(-6))$

$\alpha=1,27286558 \mathrm{~dB}$

5. Redaman satu sambungan dengan sleeve protection

$4 \mathrm{~cm}$

Diketahui : Pin $=1 \mathrm{~mW} ;$ Pout $=11,21 \mu \mathrm{W} ; \mathrm{L}=10 \mathrm{~m}$

Ditanya : $\alpha$ ?

Jawab

$\alpha(\mathrm{dB})=10 / \mathrm{L} \log$ :(Pin/Pout)

$\alpha=10 / 10 \log 0(1 \mathrm{~mW} /(11,21 \mu \mathrm{W}))$ 


$$
\begin{aligned}
& \alpha=10 / 10 \log :(\llbracket 1 \times 10 \rrbracket \wedge(-3) / \llbracket 11,21 \rrbracket \wedge(-6)) \\
& \alpha=1,95039439 \mathrm{~dB}
\end{aligned}
$$

6. Redaman dengan adapter barrel

Diketahui : Pin $=1 \mathrm{~mW} ;$ Pout $=50,65 \mu \mathrm{W} ; \mathrm{L}=10 \mathrm{~m}$

Ditanya : $\alpha$ ?

Jawab

$\alpha(\mathrm{dB})=10 / \mathrm{L} \log ;($ Pin/Pout $)$

$\alpha=10 / 10 \log :(1 \mathrm{~mW} /(50,65 \mu \mathrm{W}))$

$\alpha=10 / 10 \log :(\llbracket 1 \times 10 \rrbracket \wedge(-3) / \llbracket 50,65 \rrbracket \wedge(-6))$

$\alpha=1,29542055 \mathrm{~dB}$

Hasil Perancangan dibahas dan dibandingkan dengan hasil Perancangan dari artikel yang diacu, jika mungkin.

\subsection{Pengujian dengan OTDR}

Selanjutnya melakukan pengujian dengan optikal time-domain reflectometer untuk melihat gambar atau grafik dan juga melihat informasi mengenai kabel fiber optik seperti redaman, loss sambungan, loss antara dua titik ataupun loss konektor. Berikut tampilan padagambar 7 pengujian OTDR :

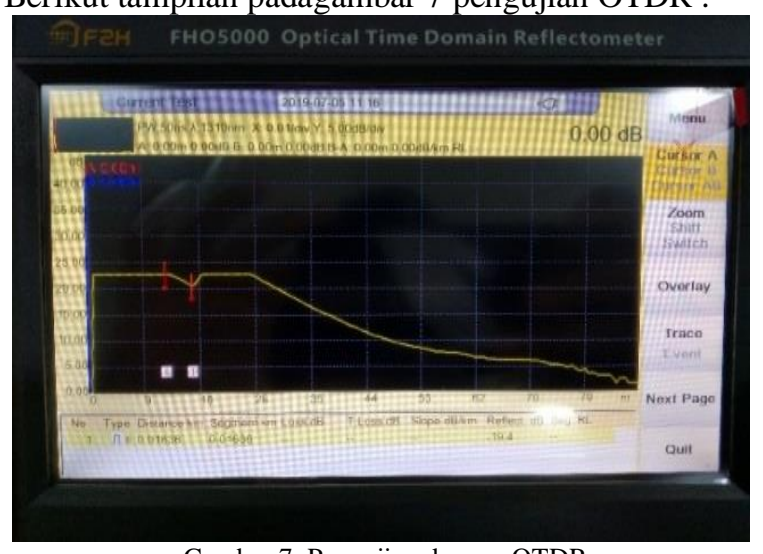

Gambar 7. Pengujian dengan OTDR

Pada gambar 7. diatas tidak didapatkan hasil dalam pengujian menggunakan optikal time-domain reflectometer, karena dalam penggunaan optikal timedomain reflectometer membutuhkan panjang fiber optik minimal 200 meter. Sedangkan panjang fiber optik dalam perancangan ini 10 meter.

\subsection{Pembahasan}

Pada penelitian ini telah dilakukan sebuah perancangan sistem yang berjudul "Merancang sistem pengukuran redaman transmisi kabel optik single mode jenis pigtail “. Serat optik atau yang sering disebut dengan fiber optik merupakan sebuah saluran transmisi yang terbuat dari kaca atau plastik yang digunakan untuk mentransmisikan sinyal cahaya dari suatu tempat ke tempat lain. Pada Perancangan ini kabel fiber optik yang digunakan adalah jenis pigtail dengan tipe kabel singlemode. Kabel fiber optik jenis pigtail ini memiliki panjang gelombang $1310 \mathrm{~nm}$ kemudian juga mengetahui panjang gelombang untuk suatu kabel itu dengan mengetahui panjang kabel, jika kabel kurang dari $10 \mathrm{~km}$ maka panjang gelombangnya $1310 \mathrm{~nm}$.

Perancangan ini membahas pada faktor penyambungan, metode penyambungan yang digunakan yaitu dengan fusion splicing. Teknik penyambungan serat optik dengan metode penyambungan fusion splicing merupakan penyambungan serat optik yang dilakukan dengan cara melakukan pemanasan pada ujung sambungan dan menggunakan lelehannya sebagai perekatnya sehingga terbentuk suatu sambungan kontinu dan juga metode penyambungan fusion splicing ini untuk menyambung dua fiber secara permanen dan rugi-rugi penyambungan yang didapat pun kecil.

Penggunaan sleeve protection berguna sebagai pelindung kabel fiber optik yang telah di sambung dengan alat fusion splicer supaya sambungan tidak patah. Ukuran sleeve protection yang digunakan pada perancangan ini yaitu sleeve protection $6 \mathrm{~cm}$ dan sleeve protection $4 \mathrm{~cm}$. Pada teknik penyambungan yang menggunakan sleeve protection ini, teknik penyambungan yang dilakukan pada satu pigtail itu dengan satu kali penyambungan dan pigtail berikutnya dengan dua kali penyambungan. Selain penggunaan sleeve protection pada perancangan ini juga melakukan teknik penyambungan menggunakan konektor yaitu adapter barrel. Pada proses penyambungan ini menggunakan alat fiber cleaver dan fusion splicer, yang mana fiber cleaver itu merupakan alat untuk memotong kabel fiber. Sedangkan fusion splicer merupakan alat penyambungan serat optik dengan memanfaatkan panas untuk meleburkan kedua ujung kabel optik secara bersamaan, fusion splicer ini metode yang paling efektif, karena metode ini menghasilkan redaman yang paling kecil.

Proses penyambungan, terlebih mengkupas kabel fiber dengan fiber stipper kemudian membersihkan cladding dengan alkohol. Dalam tahap membersihkan cladding ini harus dipastikan bersih, karena ini dapat mempengaruhi dalam tahap pemotongan, jika fiber belum bersih maka proses pemotongan tidak sempurna. Pemotongan core pada pigtail menggunakan alat fiber cleaver. Setelah proses pemotongan selesai dilanjutkan dengan proses penyambungan menggunakan alat fusion splicer. Perancangan sistem ini menggunakan 6 kabel fiber optik jenis pigtail yang nantinya akan di pasang pada OTB 6 core, yang mana core yang pertama itu tanpa sambungan, core yang kedua penyambungan dengan sleeve protection $4 \mathrm{~cm}$, core ketiga dua sambungan dengan sleeve protection $4 \mathrm{~cm}$, core yang ketiga satu sambungan dengan sleeve protection $6 \mathrm{~cm}$, core keempat dua sambungan dengan sleeve protection 6 $\mathrm{cm}$, dan core yang terakhir dengan penggunaan konektor adapter barrel. Setelah 6 core telah terpasang pada OTB, maka selanjutnya melakukam pengukuran.

Pada saat tahap pengukuran, fiber optik diberi cahaya sumber oleh light source pada OTB A RX dan melihat daya yang diterima pada OTB B TX dengan 
alat ukur OPM dan OTDR. Pengukuran pertama dilakukan dengan alat ukur OPM, data pengukuran untuk tanpa sambungan dapat dilihat pada tabel 1 , juga data pengukuran penggunaan sleeve protection $4 \mathrm{~cm}$ satu sambungan pada tabel 2, tabel 3 data pengukuran untuk sleeve protection $4 \mathrm{~cm}$ dua sambungan, tabel 4 data untuk penggunaan sleeve protection $6 \mathrm{~cm}$ satu sambungan, dan tabel 5 data pengukuran untuk sleeve protection $6 \mathrm{~cm}$ dua sambungan, kemudian data pengukuran untuk penggunaan konektor adapter barrel pada tabel 6.

Setelah proses mengambilan data telah selesai, dapat dilihat perbedaan nilai redaman antara penggunaan sleeve protection $6 \mathrm{~cm}$ dan $4 \mathrm{~cm}$, dan dengan satu sambungan ataupun dua sambungan. Pada penggunaan sleeve protection, penggunaan sleeve protection $6 \mathrm{~cm}$ memiliki nilai redaman yang kecil dari pada penggunan sleeve protection $4 \mathrm{~cm}$. Lalu, dilihat dari jumlah sambungan, yaitu satu sambungan dan dua sambungan, bahwa dengan dua sambungan nilai redaman akan tinggi dari pada satu sambungan, maka dapat di artikan, semakin banyaknya penyambungan yang dilakukan dalam satu kabel itu, semakin tinggi nilai redaman yang dimiliki. Dan juga dalam penggunaan adapter barrel nilai redaman lebih tinggi jika di banding dengan penggunaan sleeve protection karena prinsip dari adapter barrel ini hanya meneruskan cahaya, karena itulah nilai redaman tinggi dimiliki oleh adapter barrel ini

Sedangakan pengujian dengan menggunakan optikal time-domain reflectometer tidak dapat dihasilan data redaman sambungan, karena dalam penggunaan optikal time-domain reflectometer membutuhkan panjang fiber optik minimal 200 meter. Sedangkan panjang fiber optik dalam perancangan ini 10 meter

\section{KESIMPULAN}

Setelah dilakukannya pengukuran dan perhitungan data redaman dapat diambil kesimpulan sebagai berikut :

1. Metode penyambungan serat optik menggunakan fusion splicer merupakan metode yang paling efektif, karena metode ini menghasilkan redaman yang paling kecil.

2. Setelah dilakukannya pengukuran menggunakan alat ukur OPM dan OTDR, dapat dilihat bahwa perbedaan nilai atau selisih nilai dari kedua alat ukur ini kurang lebih dua angka.

3. Penggunaan sleeve protection dengan ukuran $4 \mathrm{~cm}$ dan $6 \mathrm{~cm}$, dapat disimpulkan bahwa penggunaan sleeve protection $6 \mathrm{~cm}$ lebih kecil redaman yang dihasilkan dari pada penggunaan sleeve protection $4 \mathrm{~cm}$.

4. Faktor penyambungan dengan satu sambungan lebih kecil nilai redamannya dari pada dengan dua sambungan. Jadi, jika semakin banyak penyambungan maka nilai redaman semakin besar.
5. Pada penggunaan adapter barrel, redaman lebih tinggi dengan adapter barrel dibanding dengan penggunaan sleeve protection.

6. Pengukuran redaman dilakukan dengan perhitungan, yang dilakukan dengan rumus decibel berikut ; $\mathrm{L}(\mathrm{dB})=10 \log ($ Pout/Pin $)$..

\section{UCAPAN TERIMA KASIH}

Penulis mengucapkan terima kasih kepala laboratorium Telekomunikasi yang telah mengizinkan untuk menggunakan beberapa alat uji dan kepada Politenik Negeri Padang yang telah membiayai penelitian ini melalui dana DIPA tahun 2019 dengan Nomor : :169/PL9.1.4/PT.01.02/2019,Tanggal 30 Agustus 2019

\section{REFERENSI}

[1] E. K. Wadhana, I. H. Setijono, and M. Sc, "KOMUNIKASI SERAT OPTIC MENGGUNAKAN METODE OPTICAL LINK," pp. 1-11.

[2] R. E. N. P. Iswan Umaternate1, M. Zen Saifuddin2, Hidayat Saman3, "Sistem Penyambungan dan Pengukuran Kabel Fiber Optic Menggunakan Optical Time Domain Reflectometer ( OTDR ) pada," vol. 0, no. 1, pp. 26-34

[3] F. Hilman, "Perancangan dan Implementasi Fiber Optic di Lab.Komunikasi Bergerak Gedung Elektronika Politeknik Negeri Balikpapan," 2018.

[4] D. I. Pt, T. Indonesia, T. Area, N. Solo, T. Elektro, U. Diponegoro, J. P. H. Soedarto, S. Kode, and P. Telp, "TEKNIK PENYAMBUNGAN SERAT OPTIC DENGAN METODE PENYAMBUNGAN FUSI ( FUSION SPLICING )," no. 195906191985111000 , pp. 18.

[6] M. M. A. Lf, S. T. Mt, T. Elektro, U. Diponegoro, J. P. H. Soedarto, S. Kode, and P. Telp, “TEKNIK PENYAMBUNGAN METODE PENYAMBUNGAN MECHANICAL PADA SERAT OPTIC ( MECHANICAL SPLICING )," pp. 1-9.

[6] I. Umaternate and Z. Mabud, "Sistem Komunikasi Serat Optic dengan Metode Power Link Budget pada Link Sofifi-Jailolo di PT . Telkom Sofifi," vol. 4, no. 1, pp. 20-29 